\title{
STRATEGY TO INCREASE BRAND AWARENESS OF COFFEE "HABEN NAGEN"
}

\author{
Noor Udin, Arif Prijono Susilo Ahmad ${ }^{1 *}$, Sari Ramadanty ${ }^{1}$ \\ Visual Communication Department, School of Design \\ Bina Nusantara University, Jakarta 11480 Indonesia \\ "nudin@binus.edu
}

\begin{abstract}
The increase of coffee lovers in Indonesia is marked by the growing coffee business in various parts of the archipelago, both retail and large-scale business. Now, drinking coffee is more than a habit, but a lifestyle. These coffee connoisseurs are even included as part of the "third wave coffee" which shows that they not only enjoy coffee, but also look at its history, processing, presentation, and making the taste The spirit of Haben Nagen coffee as a brand of coffee should be pinned on the market situation above. It's time to strengthen the Haben Nagen brand to make it the top choice for coffee lovers in the Mount Puntang area and its surroundings. Because this area has a huge tourism potential, especially for coffee lovers. To achieve this goal, the stages of brand strengthening will be used through 1. Branding awareness, 2. Building brand identity 3. Application of branding activities and 4. Evaluation and guidance for the independence of the brand. In the end, it is expected that the brand will become an entity that has a better brand value so that ultimately the brand equity of Haben Nagen will increase.
\end{abstract}

Keywords: Coffee, brand awareness, brand identity

\section{INTRODUCTION}

Drinking coffee is not only a necessity, but a lifestyle. The connoisseurs of this coffee are even included as part of the "third wave coffee" which shows that they not only enjoy coffee, but also view its history, processing, presentation, to taste the taste. In addition to the Tempo edition of March-April 2018, the Ministry of Agriculture noted that coffee production in the country over the past few years reached an average growth of $0,93 \%$ with consumption growth reaching an average of $2.43 \%$. This consumption rate is around 8 percent higher per year above world consumption growth. On the other hand, encouraging SME entrepreneurs to have branding awareness is not an easy thing. An appropriate strategy is needed to improve understanding of brand value as a whole. The term branding is still very foreign among SME actors, including for the managers of Haben Nagen Coffee, so assistance that involves academics is needed. Brand is defined by various sources with several approaches. An association in America, the American Marketing Association defined the brand in 1960 defines that a brand is a name, terminology, sign, symbol, design, or combination of several elements that direct the identity of an item or product or service so that it has a distinctive with similar products or services. Some SMEs do not see that big brands like IKEA start from small furniture businesses in Sweden, or McDonald's is a very simple food stall in California.

Small and Medium Enterprise Brand Awareness is based on the lack of understanding of branding or brands for SMEs who are characterized by the assumption that brands are merely labels, not as part of a strategy (Noor, 2011). The branding activity they know is a cost center (profit center) not a source of profit so that its existence is still underestimated. Another thing that makes us aware that the weakest point of SMEs is capacity building, namely the ability (knowledge, skills, attitude) of SMEs in building Indonesian SME brands that are world class competitiveness (Yuswohadi 2013). The rise of SME actors is the beginning of awareness of local uniqueness that still provides enough free space. Local challenger in competing with global brands by utilizing local uniqueness to win the competition. This underlies the research we planned which is projected to be a guide for the creation of the Haben Nagen coffee branding program. 
The digital era influences the behavior and culture of coffee lovers in Indonesia, compared to what happened five or seven years ago, where looking for coffee shops is not as easy as now. With the entry of one of the foreign coffee shops like Starbucks, it turned out to have a major influence on the urban lifestyle. Yes, there is no denying that the presence of foreign coffee outlets makes the name of local coffee and other coffee-drinking cultures thrive. (viva, 2018)

Mount Puntang in Banjaran District, Bandung, which is at an altitude of 2,223m is one of the best quality coffee producing regions in the world. One of the things that increasingly makes this local coffee known to the world is its success in being a champion at the 2016 international coffee festival, in the city of Atlanta, United States. The coffee planted on Mount Puntang is the best type of Arabica seeds, including Red Bourbon and Yellow Catura. Planted by approximately 150 local farmers in an area of 400 hectares with an altitude of 1,300 meters above sea level. The type of coffee that comes from Mount Puntang has a sweet and slightly sour taste in coffee that fits perfectly in the tongue. This is a potential resource derived from soil elements and water content that determines the quality of coffee. Based on these qualities, the type of coffee that can grow Robusta and Arabica. The way coffee cultivation is done by farmers is done in an organic way. Planting and maintaining plants without involving chemicals, harvesting fruit by picking red, and proper drying affect the taste and aroma of Puntang coffee beans.

The name "Haben Nagen" is taken from the Sundanese language Karuhun which means "continue to survive". The meaning of the name "Haben Nagen" means that Puntang's coffee must continue to survive. The "Haben Nagen" brand has the desire that the coffee they sell can represent Puntang coffee which can be preserved and widely known by the public. "Haben Nagen" coffee is managed in collaboration with local coffee farmers to create products with the concept of premium coffee products or commonly known as specialty coffee. Premium coffee or special coffee is the name of high-quality coffee with unique coffee bean flavor.

The advantages of Haben Nagen coffee above will not be known and responded well by the coffeelovers community if branding is not carried out. To strengthen the Haben Nagen brand to consumers, the first step taken is to understand the importance of brand awareness. Brand awareness is the ability of the audience or potential customers in remembering, recognizing or realizing a brand for product categories, values rationally as well as emotional value. Elements of Brand Identity include names, logos, slogans, or jingles of a brand. Perrey Jesko, author of the book Retail Marketing and Branding said that nothing strengthens a brand more than awareness (Perrey, 2013).

Brand Awareness development process, it is necessary to have a positioning analysis to determine the position of the Haben Nagen brand. One reference that is commonly used in making positioning analysis is based on Competitor Analysis and Opportunity Analysis. Competitor Analysis aims to be able to find out the competitive advantage and weaknesses of competitors. How to identify a competitor is to know clearly what type of product offered by a competitor, to see the market size of the competitor through the market segment that will be entered. Based on the analysis of conditions in the field, it is known that currently the main competitors of the Haben Nagen brand are Puntang Coffee and Wangun Coffee. Some of the other brands that are in Bandung, among others: Haben Nagen, Puntang Coffee, Wangon Coffee, Murbeng Puntang, Morist Coffee, Madali Puntang and Blue Preanger.

Based on Opportunity Analysis, it is known that currently the Haben Nagen brand still has several advantages compared to other competitors. Some of its advantages include (1). Haben Nagen is the coffee manager who buys the most from local farmers. (2). Is a Brand that carries the concept of specialty coffee. (3). Having good communication with farmers because it is part of the community of Mount Puntang Coffee Farmers (4). Having a sales spot that facilitates sales on Jalan Gunung Puntang KM 29, Pasirmulya, Banjaran, Bandung. (5). Having a lower sales price compared to other competitors.

Based on the Competitor Analysis and Opportunity Analysis the initial positioning of the Haben Nagen brand has advantages compared to competitors and has better benefits. For this reason, the aim of community service is to create a "Brand Awareness Strategy for Haben Nagen Coffee"

\section{Partner Problems}

Based on the analysis of the situation that has been described, there are several problems, namely:

(1). The absence of a SWOT analysis that can help the formation of Brand Identity and Brand Architecture from the brand manager "Haben Nagen". (2). The absence of a consistent visual identity 
on "Haben Nagen" coffee products. (3). There is still a lack of understanding of coffee managers "Haben Nagen" about branding strategies. (4). Low level of awareness that coffee "Haben Nagen" is a coffee product that carries the theme of specialty coffee.

\section{Program Solution And Implementation}

In the midst of the high competition for new coffee brands popping up, the need for an effective branding strategy to build awareness of better Haben Nagen coffee. Brand awareness is one of the factors that businesses need to strengthen the value or value of their products on the market (Keller, 2012). To form Brand awareness, a brand must have a brand architecture that can be expressed by a good brand identity. In building a brand, many things must be planned such as: (1). Design visual identity, which includes logos, packaging, signage, building exterior and interior, uniforms, company profiles, standard manual graphics, and many more; (2). Designing communication, such as: advertising, annual reports, public relations, etc .; and (3). Establish overall actions, which include: company value, work ethic, corporate culture, and others (Oscario, 2013).

Planning of branding strategies requires systematic stages of awareness about the existence of Haben Nagen coffee to further understanding so that it is recognized by its advantages or unique to sell Haben Nagen Coffee prepositions. Needed the right touch point brand so that potential customers place Haben Nagen coffee as their preferred coffee list. The first thing a prospective customer does is to come into contact with the brand name and a visual identity of a brand. They will go through stages of interest if the touch point is visually or verbal attention in the form of naming and an interesting identity. So, what is done further is search or searching in the scope of their daily lives, which can be in the form of direct interaction, personal or community, also media penetration such as print, electronic and digital media. The next process is determining the decision to make a purchase that is categorized as an affective process. If potential customers are already in the affective phase they are likely to continue in the action phase.

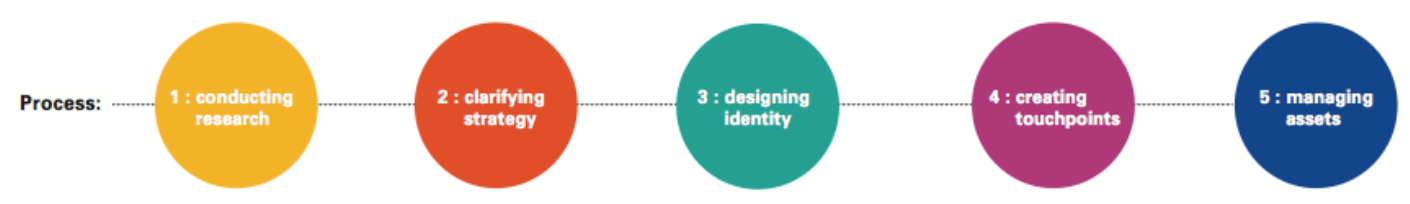

Figure1. Work of Flow proses branding (Wheeler, 2009)

In increasing brand awareness, as an initial step there needs to be a SWOT analysis (Strength, Weakness, Opportunity, Threat). After that, it is necessary to investigate the Vision and Mission and local values that can increase the value of the product. One medium that is currently popular which is used to increase public awareness about a brand is to use social media.

The ability of social media in creating awareness and at the same time can help product sales growth. The advantage of using social media in shaping a brand's awareness is because it can reach more and more segmented audiences. The type of social media that is often used as a branding strategy in communicating products is Facebook, Instagram and Youtube. Content is the key to power in communicating a product through social media. Interesting content and packed with simple stories into a popular new method. The content packaging method is known as the "Storytelling" method.

Based on the problems that have been revealed, the solutions offered are understanding and training on identity design to packaging design for coffee managers "Haben Nagen". Furthermore, in making branding strategies, the solution offered is to provide understanding and training on the importance of Brand Identity formation and Brand Architecture through Core values, Brand attributes, Competitive Advantage, and Brand strategy.

\section{METHOD}

The method of implementing the Community Development Program (PKM) Implementation of the Branding Strategy Strengthening the Brand Awareness of Haben Nagen Coffee uses the R \& D of the consumer-based approach to (Heiding, 2009). Brand Management, Research, Theory and 
Practice. Heiding began his method by collecting assumptions through the measurement of equity or the value of the brands as objects of research, then carried out with the alignment of related theories to be further combined with methods and data, so that the results of the analysis were obtained as proposed applications.

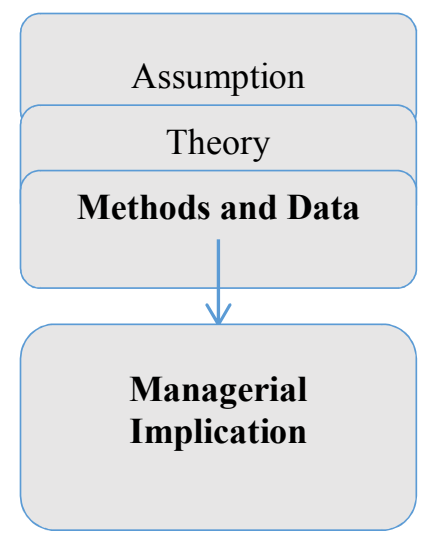

Figure 2. Diagram of Methods and data of the consumer-based approach

The main thing that is done in this community independence program is to measure the value of equity contained in the Haben Nagen Coffee product or brand as a mapping basis obtained. Initial data collection is done by extracting data through the internet, direct interviews with Hagen Nagen coffee managers, competitor analysis and visual audit of existing visual identities.

\section{Observations}

Conservation has been done by visiting Haben Nagen cafe directly, meeting with management teams, farmers and visiting coffee plantations in the Mount Puntang area. In this activity, interviews and flavor comparison tests were conducted from various types of coffee offered at Haben Nagen Café. Conservation is carried out in the period 17-18 January 2018.

\section{Training: Understanding Branding}

The material of this activity covers how a brand can provide more value to the company. Brands can be well identified by Haben Nagen consumers. The training material also contains stages of building a brand from positioning, naming, developing identity, applying identity to packaging, stationary, signage, and other items. This training is delivered by the team with their respective expertise. An understanding of branding opens a new perspective for Haben Nagen Coffee managers in planning branding activities in the future.

\section{RESULT AND DISCUSSION}

The application of the concept of branding strategy on Designing Brand Identity (Wheeler, 2009) becomes a measuring tool for the validity of assumptions obtained from initial observations. Data collection is controlled by using branding method that contains assembled brand touch point information (Wheeler, 2009), so that it narrows towards the research findings that will be used as recommendations for managerial solutions and Haben Nagen Coffee brand applications practically and easily applied by Haben Nagen coffee managers so able to have better competitiveness. The steps taken are in the form of alignment (check points) since formulated a vision which is a Haben Nagen brand idea, the actions of its stakeholders to how the concept of branding is expressed visually and verbally. An effective branding strategy also brings together harmonized communication from various elements of the Haben Nagen coffee brand from farmer partners, managers and leaders, employees and advocates. This union will work thoroughly covering products, services effectively from time to time. 


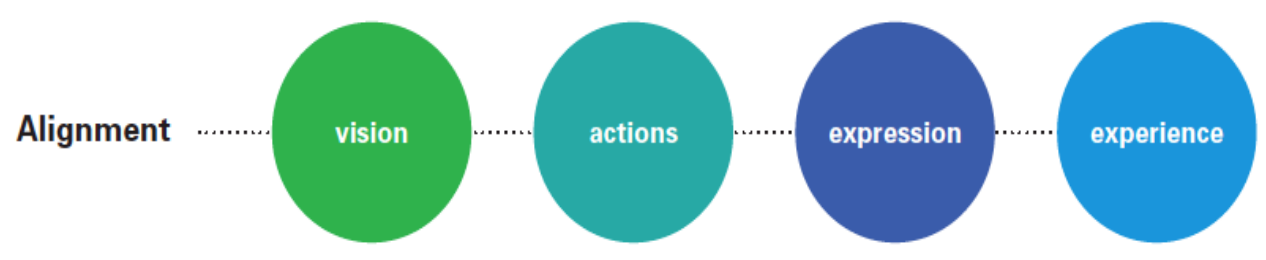

Figure 3. Alignment of branding strategies for Haben Nagen coffee

\section{CONCLUSION}

On the delivery of understanding branding material on April 25-26 2018, a visual audit was carried out on the visual identity of Haben Nagen coffee. Haben Nagen Coffee has several different logos. This has become an initial meeting where the research team recommends that Haben nagen coffee has a standard logo (logogram and logotype) so that it is easily recognized by consumers. In the visual audit session also found that Haben Nagen coffee has a variety of packaging designs with different visual approaches, so there is no unity, this is not very beneficial for the Haben Nagen brand. These preliminary findings strongly support the brand awareness proposal which starts from understanding branding, how to implement the branding strategy of Haben Nagen. As a continuation of the branding strategy, on September 2, 2018, a new Haben Nagen Coffee visual identity was established and its application in stationary kits, packaging design, signage, and several other promotional items. The launching of a new Haben Nagen Coffee identity was launched at the Binus Bangun Desa Festival, in Pasir Mulya, Banjaran, Bandung.

\section{REFERENCES}

Keller, Kevin Lane. (2012). Strategic Brand Management: Building, Measuring, and Managing Brand Equity, 4th Edition $4^{\text {th }}$. Pearson, UK

Oscario, Angela. (2013). Pentingnya Peran Logo dalam Membangun Brand. Jurnal Humaniora, Vol.4 No.1, 191-202, Jakarta: Binus University

Perrey, Jesko. (2013) Retai Marketing and Branding, 2nd Edition, A John Willey and Son, Chichester, West Sussex, UK

Udin, Noor (2011), Langkah Penyadaran Brand Usaha Kecil dan Menengah. Jurnal Humaniora, Vol 2 No.1, Jakarta: Binus University.

Wheeler, Alina (2009), Designing Brand Identity, 3rd Edition, New Jersey: Wiley \& Sons, Inc.

Yuswohadi, Dyah Hasto Palupi, Teguh S. Pambudi (2013), Beat the Giant, Jakarta: Gramedia Pustaka Utama. 